Research Journal of Applied Sciences 13 (4): 275-284, 2018

ISSN: $1815-932 \mathrm{X}$

(C) Medwell Journals, 2018

\title{
Technical Efficiency and Resources Use among Wheat Producers in Southwestern Libya; An Application of Slack-Based Measure of Efficiency
}

\author{
${ }^{1}$ Hanan Ali Mohamed Alabasi, ${ }^{1}$ Zainalabidin Mohamed, ${ }^{1}$ Ismail Abd Latif, \\ ${ }^{1}$ Amin Mahir Bin Abdullah and ${ }^{2}$ Abdullahi Iliyasu \\ ${ }^{1}$ Department of Agribusiness and Bioresource Economics, Faculty of Agriculture, \\ University Putra Malaysia, 43400 Serdang, Selangor, Malaysia \\ ${ }^{2}$ Department of Agricultural Economics, Faculty of Agriculture, University of Maiduguri, \\ Maiduguri, Nigeria
}

\begin{abstract}
Over the last decade, although, the planting area of wheat increased, the yield is still at same lower level and there is no significant improvement in wheat yield per hectare, though some farms are quite efficient and are using accordingly during the process of production. The present study applied the slack-based measure of efficiency to determine technical efficiency of wheat producers in the South-Western Libya during 2015 cropping season. In the same token, a Tobit Model was regressed to examine the determinants of technical inefficiency among wheat farmers. Evaluation of technical efficiency as well as input slacks, offers an important understanding of the wheat farm's performance in terms of resource utilization which enables effective formulation of policies. The result shows that wheat farmers have a great chance to enhance their production and productivity by better use of the inputs and the government could increase the productivity of wheat by focusing on motivating and encouraging the younger generation of educated farmers. Furthermore, the usage of improved seeds could be recommended to inefficient farms to assist them in catching up with other farms with the best practices.
\end{abstract}

Key words: Technical efficiency, slacks-based measure model, inefficiency, wheat, Libya, production

\section{INTRODUCTION}

Wheat crop is a staple food for Libyans and considered as one of the most important cereal crops grown in the country. This is due to the use of wheat flour in the manufacture of bread, pasta, biscuits and other wheat-related industries. Due to this importance of wheat crop, the government encouraged the private sector to grow it. Wheat is a winter crop and generally grows under two types of farming conditions; irrigated agriculture in which located in the Libyan South and rain feed agriculture situated in Northern Libya. Wheat is usually planted in the mid of November and the harvest takes place in the mid of May and the production cycle is about 6 months. During 2007 and 2017, the total land area for wheat planting has increased to 165,000 ha with a percentage change of $25 \%$. On the other hand, the level of production increased from $130,000 \mathrm{MT}$ in 2001 to about $200,000 \mathrm{MT}$ in 2017. Southwest Libya provides about 53\% of total wheat production, Marj area in the East of Libya is the second area for wheat production it provides about $16 \%$ of total wheat production in Libya (Department of
Statistics Libya). Libya is a desert country with a poor water source and renewable sources but it is rich by the groundwater that was stored from the days of rain period, thereby farmers depend on irrigated agriculture by $90 \%$ to irrigate agricultural crops.

On the other hand as seen in Fig. 1, a yield gap, the difference between actual and potential yield is reflecting the efficiency of resources use and it is generally large in developing and transitional countries (Bai and Tao, 2017).

In a bid to handle the demand and supply gap, the department of agriculture and Libya grains organization have embarked on many policies to increase wheat production; the seeds subsidies through (NCISP) help farmers to get the improved seed as well as modern mechanization. Furthermore, the facilities provided for farmers to get the loans by the ministry of agriculture, animal and marine wealth also helped to increase the number of farms and production (Lariel, 2015). However, the government efforts to increase the productivity of wheat will not be effective if not combined with the rational use of the inputs by the farmers. The current

Corresponding Author: Hanan Ali Mohamed Alabasi, Department of Agribusiness and Bioresource Economics, Faculty of Agriculture, University Putra Malaysia, 43400 Serdang, Selangor, Malaysia 


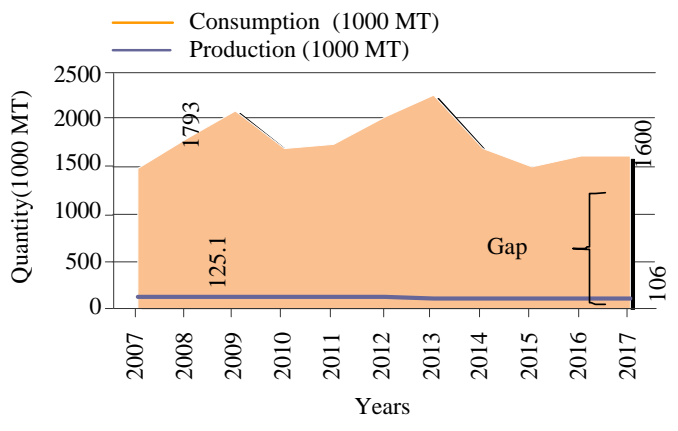

Fig. 1: Yield gap of wheat in Libya

wheat production in Libya is about 200 thousand MT and it just covers about $27 \%$ of the needs of the population, in which almost about 1.6 million MT and the average yield about $1.25 \mathrm{MT} / \mathrm{ha}$ and this level is low comparing to the global wheat yield which is about 4.6 MT/ha.

The level of the wheat crop in Libya is reduced over the last decade, indicating that there is a problem with the use of input in production cycle which makes the yield of wheat continue to decrease. Though some farms are quite efficient and are using inputs accordingly during the process of production, nevertheless, a lot of wheat farmers are still using the traditional methods of production. In order to achieve efficient use of inputs in the production process, it is imperative to have the initial information during the measurement of wheat farms.

Measuring efficiency of wheat farmers seems necessary in order to understand the status of the farmer's ability and the use of input during the production process. In determining the factors either, technical in nature or the farmer's soft skills are very important because these factors will affect the efficiency and could also be accountable for the inefficiency, leading to low productivity of wheat yield in Libya or at an optimal level. Measurement of technical efficiency helps to quantify the proportional increase in output which might be obtained by the improved use of inputs. Therefore, in order to have sustainable policies, it is necessary to focus on neglected sides which related to the resources used and combine it with the created policies.

Literature review: According to Koopmans (1951), the producer is a technically efficient if outputs maximized with a given level of inputs. Farrell (1957) suggested that producers do not only deal with a production function, they also face profits and cost function. Farrell divided efficiency to technical efficiency and allocative efficiency. On the other hand, technical efficiency decomposes into pure and scale technical efficiency. Conventional methods to measure the level of efficiency conducted by estimating an average production function, Marginal Value Product (MVP) of each input and Marginal Factor Cost (MFC) have been widely used in agricultural research. Recently, a number of alternative frontier approaches have been used for measuring the efficiency. The most popular frontier approach for measuring efficiency is the (stochastic frontier approach) and data envelopment analysis and each frontier technique that involve different models for the measurement of best practice for DMUs. Amongst all different, the frontier approaches, DEA, developed by Charnes et al. (1978) has widely applied over the stochastic frontier approaches. The most important advantage of DEA is that it does not need to put State hypothesis (Mathematical formula) for the function that links between dependent and independent variables as in the case of production function (Sav, 2017). In addition, DEA determines a best practice efficiency frontier that can be used and gives each firm a full picture of performance. DEA is also taking into consideration returns to scale, this is a useful feature because when calculating efficiency, it allows the use of the concept of increasing or decreasing efficiency based on size and output levels.

However, DEA provides two types of measurement: first is radial a model in which assumes that the proportional change of inputs or outputs and usually ignore the slacks in measuring efficiency scores. Radial measures are represented by the conventional DEA Model. The second is non-radial models; the inputs/outputs are allowed to decrease/increase at different rates. These measures consider the slacks of each input or output and the variety of inputs and outputs are not proportional Tone (2017). These models include a Slacks-Based Measure (SBM). In this study, we applied the Slack-Based Model (SBM) to measure technical efficiency and examine the slack values which are not examined in most previous studies which only worked out to estimated technical efficiency. Apart from this, the study applies the Tobit Model to determine factors response to technical inefficiency.

This research is based on the assumption that technical efficiency is one of the keys to improve the level of wheat productivity in Libya. Thus, lack of rational use of inputs leads to lower expected production and productivity. Many studies have been done on the technical efficiency of wheat production among different country in the world. Different factors have been identified that carry a significant effect on technical efficiency on wheat production such as farm size, seed, pesticides, fertilizers, labor and machines Usman et al. (2016), Tiruneh and Geta (2016) and Tavva et al. (2017). 
However, a large number of studies adopted their analysis based on the size of the farm which is that the technical efficiency between farms different by the difference in size (Bhatt and Bhat, 2014; Mirza et al., 2015; Hashmi et al., 2015). On the other hand, different environmental conditions between regions have made some studies focus on this factor in efficiency analysiswhere technical efficiency varies according to environmental conditions (Chebil et al., 2016; Buriro et al., 2013).

Some previous studies have reported that farm size had a significant effect on production rather than productivity. The level of yield can be increased by allocating more area for production Bhatt and Bhat (2014). On the other hand, it is not necessary to have large-scale farms to only be efficient, small-scale farms may found more and can be more efficient in case of allocating the resources and competence. According to Hashmi et al. (2015), small farms are more efficient because of the dependence on self-operated and family members as labors in addition to that, small-scale farms can have control on the fertilizers and chemicals used in the process. However, although, farm size is a very important factor affecting on technical efficiency, it is important to link between the size and the farming system because may have less farm size but the technology used in agriculture is modern.

The impact of agricultural labor on the efficiency is two-fold; the type of labors (family or hired labor) and the age of farmers. The labor effects on efficiency in terms of the number of workers. Through which effects on days and hours of work, then effecting on efficiency. In case of workers on the face of it, the hired labor usually expected to be more efficient than family labor because most of them are skilled thereby they can use inputs more efficient (Rahman et al., 2011). However, the family labor found to be more efficient than hired labor (Chirwa, 2007). On the other hand, the age of the worker affects the ability of the farmer to use modern machines, perhaps because of the lack of knowledge and it is usually dependent on the traditional method which would increase the number of hours and working days and affect the technical efficiency (Arthi et al., 2018).

The effect of seed depends on the way of utilization; overutilization of seed in which means the high values of slack when adding more than required quantity (Gambo et al., 2017) on the other hand, underutilization of seed indicating that farmers need to more allocate inputs in planting (Ajekiigbe et al., 2017). Another factor found to have a very important consequence of technical efficiency is the fertilizers. The added amounts of fertilizer depending on the method of addition, it may be using conventional machines or using modern machines and thus affected the fertilizers quantity in the agricultural cycle (Singh and Bera, 2016).

Numerous studies have measured technical efficiency of wheat production in different countries as seen in Table 1 . However, rarely studies dealing with technical efficiency of wheat production linked with the allocating of resources through slack analysis. Therefore, this study is an attempt towards measuring the technical efficiency of the wheat farmers and aims to cover the prevailing information gap on the factors affecting on efficiency differentials in the production of wheat. The contribution of the study to the existing literature on the technical efficiency stems from focused on technical efficiency as well as input slacks of wheat production in developing country like Libya.

Conceptual framework: The importance of the wheat crop is not only the main source of food for Libya, it is also the source of income for many farmers, especially in Southwestern Libya. The conceptual framework explains in Fig. 2. Farmers differed in the system of wheat cultivation. Some of them used modern machines for the purpose of increasing the production and profits while some still rely on traditional methods and old machines in wheat cultivation. It is known that the use of technology is of a great importance in the improvement and development of production but despite the progress made in the use of modern technology in the cultivation of wheat in Libya, productivity is low over the past years and there is no improvement in the productivity. The low level of production and productivity will affect the profits and farmers may be forced to abandon wheat cultivation and move to produce another more productive crop and more profitable to cover their production costs and increases their profits. This affects the amount of domestic wheat production and an increased quantity of wheat imports which has other implications for the country.

Therefore, it is necessary to analyze the inputs used in wheat production for the purpose of determining the efficiency of using these inputs to increase the productivity of wheat crops as well as to study the social factors that have a significant impact on wheat cultivation. Studies of wheat production with the socioeconomic factors of farmers in Libya are rare. On the other hand, the study socioeconomic variables in the analysis of inefficiency contribute significantly to the development of accurate policies to support wheat 
Table 1: An overview of studies on the technical efficiency of wheat production

\begin{tabular}{|c|c|c|}
\hline Researcher's and study period & Country & Results \\
\hline Usman et al. (2016) & Layyah, Pakistan & $\begin{array}{l}\text { TE scores ranging between } 0.38-1 \text { with an average of } 85 \% \text { indicating that farmers can increase } \\
\text { their production by } 15 \% \text { and still produce the current level of production }\end{array}$ \\
\hline Hashmi et al. (2015) & Punjab, Pakistan & $\begin{array}{l}\text { The average TE was } 73 \% \text { and farmers can improve their performance by increasing the level } \\
\text { of inputs usage by } 27 \%\end{array}$ \\
\hline Kalra et al. (2015) & India & $\begin{array}{l}\text { The mean TE was } 84 \% \text { and implies that farmers can increase their output by } 16 \% \text { by better use } \\
\text { of inputs }\end{array}$ \\
\hline Tiruneh and Geta (2016) & Ethiopia & $\begin{array}{l}\text { The average TE was low at } 57 \% \text { and there is an opportunity to increase it by } 43 \% \text { through } \\
\text { gender-sensitive agricultural intervention, group approach extension and attention to farmer's } \\
\text { education, scaling out of best farm practices }\end{array}$ \\
\hline Chebil et al. (2016) & Sudan & $\begin{array}{l}\text { The average technical efficiencies estimated were } 0.52,0.61,0.48 \text { and } 0.41 \text { for Gezira, } \\
\text { Kassala, Northern and River Nile, respectively. Farmers can enhance their productivity } \\
\text { by more efficient use of inputs using the same technologies }\end{array}$ \\
\hline Dagistan (2010) & Turkey & $\begin{array}{l}\text { On average the TE of wheat farmers is } 80 \% \text { which implies that farmers could save from } \\
\text { the variable inputs by at least } 20 \% \text { and still produce at the same level of production }\end{array}$ \\
\hline Tavva et al. (2017) & Afghanistan & $\begin{array}{l}\text { The mean technical efficiency of wheat farmers was } 0.67 \text { and farmers can increase wheat } \\
\text { production by } 33 \% \text { with the same level of inputs }\end{array}$ \\
\hline Wilson et al. (2001) & Eastern England & $\begin{array}{l}\text { TE was about } 87 \% \text { and farmers can still decrease their inputs by } 13 \% \text { to produce the same level } \\
\text { of output }\end{array}$ \\
\hline Ali and Khan (2014) & Pakistan & $\begin{array}{l}\text { The average TE of wheat farmers was } 62 \% \text { and the government should focus on formal as well } \\
\text { as informal education in the country by providing better educational opportunities to the rural } \\
\text { population and extension education to wheat producers }\end{array}$ \\
\hline Ibrah and Mohamed (2015) & Sudan & $\begin{array}{l}\text { The mean technical efficiencies of wheat farms were } 0.67 \text {, however, farmers who active in their } \\
\text { age, timely sowing, using improved seeds, using the tractor in land preparation and have better } \\
\text { accesses to credit tend to be more efficient. Thereby, applying technical packages and scattering } \\
\text { improved will raise the level of technical efficiency of wheat farmers }\end{array}$ \\
\hline Khanal et al. (2012) & Nepal & $\begin{array}{l}\text { wheat farmers in Nepal were operating at } 78 \% \text { level of technical efficiency and those farmers could } \\
\text { improve their performance by the good land quality and access to public irrigation thereby, } \\
\text { agricultural policies should focus on the promotion of public irrigation scheme as well as land } \\
\text { quality to improve the productivity }\end{array}$ \\
\hline Ghaderzadeh and Rahimi (2008) & Iran & $\begin{array}{l}\text { They set out many of the possible explanations for the inefficiency of rainfed wheat farmers and } \\
\text { irrigated wheat farmers in Iran and he found that both groups were less efficient about } 65 \text { and } \\
67 \% \text { for rainfed and irrigated wheat farmers, respectively }\end{array}$ \\
\hline Mirza et al. (2015) & Pakistan & $\begin{array}{l}\text { The average efficiency measurement was about } 88 \% \text { suggested that the importance improve the } \\
\text { education, especially, for older farmers as well as the importance to improve the technologies } \\
\text { to raise the productivity }\end{array}$ \\
\hline
\end{tabular}

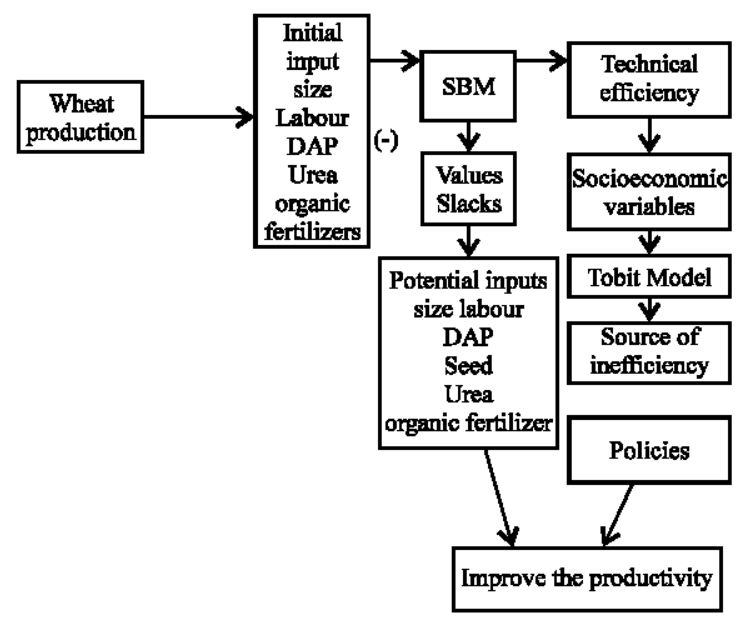

Fig. 2: Conceptual framework

productivity in Libya. Through this analysis, we can deduce the weaknesses in the use of inputs and it can inevitably help to guide the agricultural policies and lead the path to form and find solutions to increase the productivity in a limited and defined scope. In contrast, analysis the input slacks and then the expected inputs will help to give a practical solution about the input quantity which can be used in the current level of production. This section is considered an important contribution to this study in the level of the literature review about wheat production in Libya.

\section{MATERIALS AND METHODS}

Sampling method: Southwestern Libya produces about $53 \%$ of the total wheat production in Libya. The "Five States (Murzuq, Taragen, Wadi Atba, Gdwa and Um Alaraneb in the South of the Libya were purposely selected for this study and based on their findings the Murzuq area has the highest level of wheat production compared to the other areas, producing about $93 \%$ of the total wheat production in the South-West areas. The questionnaires were distributed randomly in these states due to the homogeneity of wheat production in the study area. Finally, the farmers were then selected using a simple random sampling technique.

Data collection: This study uses cross section data to gather information about wheat production in the Southwestern area of Libya as well as socioeconomic profiles of wheat farmers during the 2014-2015 production seasons. Due to the large size of the population (the 
Southwestern of Libya) and the homogeneity of production in all districts in the study area, the researcher finds that, it is more appropriate if the samples were taken from the Murzuq District because it is the main production of wheat. Through this analysis, the results can be widely circulated on the wheat farms in Southwestern Libya.

Then again in order to get a good presentation of the population, a total of 249 farmers were selected for the purpose of study using method proposed by Yamane:

$$
\mathrm{n}=\frac{\mathrm{N}}{1+\mathrm{Ne}^{2}}
$$

Margin error of 0.5 , confidence level $95 \%, \mathrm{~N}=660$, sample size $=249$ frams, a total of 249 questionnaires were distributed to the selected wheat farmers but only 225 questionnaires were correctly completed by respondents.

Analytical technique: In this study, we applied the Slack-Based Measure (SBM) of efficiency as described by (Tone, 2001) to measure technical efficiency of wheat production as well as input slacks. The importance merit of the Slack-based Model over traditional Data Envelopment Analysis (DEA) Model lies in its ability of the first to estimate efficiency scores that are unit invariant, monotone Torgersen et al. (1996). SBM comes out with more meaningful results when compared to the SFA method Tone (2001). Thus, we have applied the slack-based DEA Model for the purpose of this study. On the other hand, some of the earlier studies used the Tobit Model in the second stage of the DEA Model to determine factors responsible for inefficiency while some studies used OLS Method. The advantage of using the Tobit instead of the usual linear regression model is that it comes out with unbiased coefficient estimates for each of the variables. The Tobit regression model is under the assumption that technical efficiency is ranged between 0 and 1 and the distribution is censored distribution and not normal distribution. When the distribution is censored, OLS will yield inefficient, inconsistent and biased estimates.

\section{Model specification}

Slacks-Based Measure (SBM) of efficiency Model: The study applies the nonparametric mathematical programming approach, the SBM Slack Based Model developed by Tone (2001). It is developed to deal directly with slacks (excess inputs and output shortages) inefficiency estimation which result in estimate efficiency scores that are unit invariant, monotone and reference-set dependent Banker et al. (1984). Since, farmers have more control on inputs rather than outputs, the input-oriented slack based model was chosen for the purpose of this study. Slack-based Model (input oriented-VRS) (Tone, 2001) takes the following Eq. 1:

$$
\begin{aligned}
& \mathrm{P}_{\mathrm{in}}=1-\frac{1}{\mathrm{~m}} \sum_{\mathrm{i}=1}^{\mathrm{m}} \frac{\mathrm{s}_{\mathrm{i}}^{-}}{\mathrm{x}_{\mathrm{i} 0}} \\
& \mathrm{~s} \cdot \mathrm{t} \\
& \mathrm{x}_{\mathrm{io}}=\sum_{\mathrm{j} 1}^{\mathrm{N}} \lambda \mathrm{x}_{\mathrm{ij}}+\mathrm{s}^{-}, \mathrm{j}=1, \ldots, \mathrm{m} \\
& \mathrm{y}_{\mathrm{ro}}=\sum_{\mathrm{j} 1}^{\mathrm{N}} \lambda_{\mathrm{j}} \mathrm{y}_{\mathrm{rj}} \mathrm{s}^{+}=\mathrm{r}=1, \ldots, \mathrm{n} \\
& \lambda_{\mathrm{j}}, \overline{\mathrm{s}}, \mathrm{s}^{+} \geq 0, \mathrm{j}=1, \ldots, \mathrm{N}
\end{aligned}
$$

Where:

$\mathrm{P}_{\text {in }}=$ SBM TE

$\mathrm{s}_{\mathrm{i}}=$ Input excess

$\mathrm{s}^{+}=$Output shortage

$\mathrm{n}=\mathrm{A}$ different type of $\mathrm{y}$ products

$\mathrm{x}_{\mathrm{io}}=$ The value of inputs

$\mathrm{m}=$ The number of inputs

$\mathrm{y}_{\mathrm{ro}}=$ Output set

$\lambda=$ A non-negative vector that allows the construction of a production possibility set

\section{Definition of variables:}

- Dependent variable is quantity of wheat production (kg/ha)

- Independent variables

- Land under wheat crop (ha)

- Quantity of seed (kg/ha)

- Diammonium Phosphate (DAP) (kg/ha)

- Quantity of Urea (kg/ha)

- Labour represents total number of family and hired labor per production cycle (Man-day/ha)

- Quantity of organic fertilizers $(\mathrm{kg} / \mathrm{ha})$

Tobit regression model: The Tobit Model applied takes in the following form Tobin:

$$
\mathrm{y}^{*}=\beta_{0+} \sum \beta_{\mathrm{m}} \mathrm{x}_{\mathrm{jm}}+\varepsilon_{\mathrm{i}}
$$

Where:

$\mathrm{y}^{*}=$ Dependent variable for the $\mathrm{kth}$ farm level

$\mathrm{x}_{\mathrm{jm}}=$ The vector of independent variables

$\beta=$ Embraces the unknown parameters

$\varepsilon_{\mathrm{i}}=$ Independently distributed Error term variance

The variables and the model can be specified in its explicit form as: 
Res. J. Applied Sci., 13 (4): 275-284, 2018

Table 2: Definition of variables used in Tobit Model

\begin{tabular}{lllc}
\hline Variables & Description & Units & The expected impact on (inefficiency) \\
Age & Age of farmers by year & Year & + \\
Experience & No. of years the farmer spent in farming & Year & Level \\
Education level & Level of education & Person & Hectare \\
Household size & No. of the wheat farmer family & Dummy \\
Farm size & Size of farm by ha & Dummy & + \\
Farming system & Dummy $(1=$ modern and $0=$ traditional $)$ & Dummy \\
Member of cooperative & Dummy $(1=$ member and $0=$ otherwise $)$ & $+/-$ \\
Main occupation & Dummy $(1=$ farmer and $0=$ otherwise $)$ & - \\
Seed type & Dummy $(1=$ non improved seed, $0=$ improved seed $)$ & - & Dummy \\
\hline
\end{tabular}

$$
\begin{aligned}
& \mathrm{y}^{*}=0+1 \text { age }+2=\text { Farm size }+3=\text { Farming system }+ \\
& 4=\text { Education level }+5=\text { Years of experience }+ \\
& 6=\text { Main occupation }+7=\text { Number of family labor }+ \\
& 8=\text { Household size }+9=\text { Member of cooperative }+u \\
& y^{*}=\text { Technical inefficiency }(1-T E)
\end{aligned}
$$

Definition of variables used in the Tobit Model: Table 2 shows the definition of variables used in Tobit Model.

\section{RESULTS AND DISCUSSION}

Descriptive analysis of data used for Slack Based Model (SBM): Table 3 summaries the descriptive Analysis of Data used for Slack Based Model (SBM). Total wheat production among sample farms on average is $2016 \mathrm{~kg} / \mathrm{ha}$ with the minimum area of 2 ha and a maximum of 22 ha. On the other hand, the high variation in the quantity of production was due to the difference in size of farms. On average, the quantity of seed use per hectare is about $150.25 \mathrm{~kg} / \mathrm{ha}$ and farmers use on average $57 \mathrm{~kg} / \mathrm{ha}$, 123 and 244 of DAP, organic fertilizer and urea, respectively.

Estimates of technical efficiency: The estimated technical efficiency using the slack-based model and the results are shown in Table 4 The Estimated average TE for wheat farmers under VRS was 0.76 which indicates that the wheat farmers could reduce their inputs by $24 \%$ and still produce the same level of output.

The $28 \%$ of farmers (about 65 farmers) has technical efficiencies of more than $90 \%$, however, $55 \%$ of farmers have a technical efficiency of $<79$ and $10 \%$ of them are very far from the production frontier.

The majority of farmers (124 farmers) has a technical efficiency of $<80 \%$. However, this also shows that a large number of farmers have a technical efficiency $>80 \%$ indicating that there is an immense opportunity for inefficient farmers to be efficient as the other farmers.

Slack variables analysis: The slack analysis is represented in Table 4. A slack variable represents an unused quaintly of inputs (excess inputs) which reflects inefficiency of using the inputs by farmers (Tone, 2001).
Table 3: Descriptive analysis of data used for SBM

\begin{tabular}{lrrrr}
\hline Inputs & Minimum & Maximum & Mean & SD \\
\hline Production (kg/ha) & 500 & 2090 & 2016 & 982 \\
Size (ha) & 2 & 22 & 9.99 & 5.56 \\
Labor (man-day/ha) & 16.28 & 87.69 & 47.40 & 19.02 \\
Urea (kg/ha) & 60 & 485 & 244.6 & 114.7 \\
Organic fertilizers (kg/ha) & 52.07 & 334 & 123.74 & 55.60 \\
Seed (kg/ha) & 42.5 & 390 & 150.25 & 64.44 \\
DAP (kg/ha) & 12 & 160 & 57.21 & 34.198 \\
\hline
\end{tabular}

Table 4: Estimated technical efficiency score of wheat farms

\begin{tabular}{lcc} 
TE ranges & Frequencies & Percentage \\
\hline $0.30-0.39$ & 4 & 1.8 \\
$0.40-0.49$ & 15 & 6.7 \\
$0.50-0.59$ & 27 & 12 \\
$0.60-0.69$ & 41 & 18.2 \\
$0.70-0.79$ & 37 & 16.4 \\
$0.80-0.89$ & 36 & 16 \\
$0.90-1.00$ & 65 & 28.9 \\
Minimum & 0.31 & \\
Maximum & 1 & \\
Mean & 0.76 & \\
\hline
\end{tabular}

Field survey, 2015

Table 5: Slack variables and expected target input by removing input slacks

\begin{tabular}{lccccc}
\hline Variables & \multicolumn{3}{c}{ Input use } & $\begin{array}{c}\text { Slack } \\
\text { Frequencies }\end{array}$ & \multicolumn{3}{c}{ Target input $^{* *}$} \\
\hline Seed (kg/ha) & 139 & 148.67 & 32.03 & 21.5 & 116.64 \\
Labor & 96 & 43.380 & 6.280 & 14.5 & 37.100 \\
(man-day/ha) & & & & & \\
DAP (kg/ha) & 72 & 76.140 & 15.95 & 20.9 & 60.180 \\
Urea (kg/ha) & 71 & 255.63 & 79.15 & 30.9 & 176.48 \\
Organic fertilizer & 140 & 121.97 & 25.11 & 20.5 & 96.86 \\
Size (ha) & 48 & 1 & 0.11 & 10.7 & 0.89 \\
\hline
\end{tabular}

Researcher's calculations: **Target input can be calculated by subtracting the number of slacks per hectare from the current input use per hectare

To improve the operations of inefficient farmers, the slacks and targets input were calculated and presented in Table 5. Fertilizers are one of the main components of wheat production, the slack values of fertilizers are quite high about $20.9,30.9$ and $20.5 \%$ of DAP, urea and organic fertilizers, respectively. This could perhaps be due to farmers believe that adding more fertilizers could improve soil quality but ignoring the negative effect of its excess inputs on production and profit. Another possible reason of fertilizer's slack is to the traditional methods in using broadcasting methods for the use of fertilizers Isin et al. (2013).

The results estimate the quantity per hectare of seed slacks to be $32.03 \mathrm{~kg} / \mathrm{ha}$ indicating that on average farmers can reduce the quantity of seeds used by $21.5 \%$ 
Res. J. Applied Sci., 13 (4): 275-284, 2018

Table 6: Tobit regression results of wheat farmers

\begin{tabular}{lccrl}
\hline Variables & Coefficient & SE & Z-statistic & Probability \\
\hline C & 0.330791 & 0.073957 & 4.472754 & 0.0000 \\
Farming system & -0.168356 & 0.025878 & -6.505735 & $0.0012^{* * * *}$ \\
Member of cooperative & -0.017387 & 0.016369 & -1.062204 & 0.288 \\
Education level & -0.004379 & 0.007676 & -0.570511 & 0.568 \\
Age & 0.003494 & 0.001330 & 2.627315 & $0.008^{* * *}$ \\
Household size & -0.004109 & 0.003235 & -1.270482 & 0.203 \\
Main occupation & -0.068405 & 0.016008 & -4.273080 & $0.001^{* * * *}$ \\
Farm size & -0.004651 & 0.002714 & -1.713933 & $0.056^{*}$ \\
Seed type & 0.034641 & 0.017468 & 1.983125 & $0.047^{* *}$ \\
Experience & -0.003153 & 0.001825 & -1.727731 & $0.054^{*}$ \\
*, ** and *** denotes $0.05,0.01$ and $^{0.000 \text { levels of significance }}$
\end{tabular}

and still produce the same level of output. The main reason for the high level of seed slacks may vary due to the sowing method used in some farms, i.e., broadcasting rather than transplanting. Another possible reason for seed slacks that farmers are unaware of the required quantities of input to use (Ahmed et al., 2016). The results also show that the percentages of labor slacks are $14.5 \%$, indicating that labor input could be decreased by $14.5 \%$ and still able to produce the same output levels. The labor slacks may be due to the use of more man-day than what is required in wheat planting. However, low level of labor slacks could be due to the presence of family labor in the processes of wheat production and also the present of a small area of farming land that does not require as many labors working on it at the same time.

As indicated earlier, it seems that on average all farms seem to have slack variables on all inputs used. Table 6 shows the slack variables amount and the target input used and this could lead to good savings for farmers if the inputs are being used and managed appropriately. The results found that on average, DAP, seed, urea, organic fertilizer, labor and farm size for inefficient farmers can be reduced to $60,116,176,96 \mathrm{~kg} / \mathrm{ha}, 37.10 \mathrm{man}$-day/ha and 0.08 ha, respectively.

The indication of these results is that low level of wheat productivity could perhaps be due to the unwise use of the inputs, thus, proving that these results have important implications on agricultural policies in order to increase wheat productivity in the area studied.

Technical inefficiency analysis: The determinants of inefficiency were estimated by using the Tobit Model. The Tobit Model was employed to quantify inefficiency effects. The estimated results of the Tobit Model are presented in Table 6 . The dependent variable was technical inefficiency; the independent variables were the socioeconomic, demographic profile of the farmers and the farm. It is expected that the regression coefficients of the independent variables to generate positive sign indicating that the variables caused the inefficiency in wheat production. The purpose of using socioeconomic, demographic and farm profiles of the farmers as independent variables is because we would like to determine which amongst the independent variables are causing inefficiency. On the other hand, the negative sign indicates that the socioeconomic, demographic and farm profiles increase the technical efficiency in wheat production.

Results from models indicate that there are six significant statistical socioeconomic factors affecting technical inefficiency. The farming system found to have a negative and statistically effect on technical inefficiency indicating that, farmers who use the modern system for wheat farming are less technically inefficient than farmers who use the traditional method. That also reflects that when farms depend on modern machines in wheat planting it can use the input more rationally. For example, a seed drill machine is used in modern farms and it has the ability to use less quantity of seed compared with the traditional method for seeding such as broadcaster this result is in line with the results by Chepng'etich et al. (2015).

The negative and significant relationship between technical efficiency and farm size reflect that the large farms are more technically efficient than small farms. This supports the importance of a good farming system because modern machinery is more economical if used in large-scale farms. This result is consistent with Tiruneh and Geta (2016), Chepng'etich et al. (2015), Usman et al. (2016) findings but contradicts Hashmi et al. (2015). However, these results are in contrast with the result by Julie et al. ( 2017), Njeru ( 2010) through finding that the inefficiency increases as farm size increase.

The education level has a negative and statistically insignificant effect on technical inefficiency indicating that educated farmers are less technically inefficient because they can improve their skills, knowledge and agricultural information about inputs usage which can make them more efficient. These results are consistent with the result by Bhatt and Bhat (2014), Sapkota et al. (2017). Due to the insignificant relationship with farmers, it means that it doesn't matter if they are educated or uneducated.

The age of the farmers has a significantly positive effect on technical inefficiency indicating that older farmers are operating less efficiently compared to their younger counterparts. This result is in line with the study by Boundeth et al. (2012), Chepng'etich et al. ( 2015). The older farmers are mostly less efficient as compared to the young farmers. Empirically, the older farmers are unwilling and incapable to adapt the technical change; they are standing strong with the old traditions and are not willing to adopt the technical innovation. 
Table 7: Age and experience of wheat farmers, cross tabulation Experiences

\begin{tabular}{lllllll} 
Age $(\%)$ & $<5$ & $5-10$ & $11-15$ & $16-20$ & $>21$ & Total \\
\hline $20-30$ & $2(25.0)$ & $6(75.0)$ & $0(0.0)$ & $0(0.0)$ & $0(0.0)$ & $8(100.0)$ \\
$31-40$ & $3(6.7)$ & $34(75.6)$ & $6(13.3)$ & $2(4.4)$ & $0(0.0)$ & $45(100.0)$ \\
$41-50$ & $4(3.6)$ & $49(44.1)$ & $42(37.8)$ & $10(9.0)$ & $6(5.4)$ & $111(100.0)$ \\
$51-60$ & $2(4.3)$ & $9(19.6)$ & $19(41.3)$ & $9(19.6)$ & $7(15.2)$ & $46(100.0)$ \\
$>60$ & $0(0.0)$ & $1(6.7)$ & $3(20.0)$ & $3(20.0)$ & $8(53.3)$ & $15(100.0)$ \\
Total & $11(4.9)$ & $99(44.0)$ & $70(31.1)$ & $24(10.7)$ & $21(9.3)$ & $225(100.0)$ \\
\hline
\end{tabular}

Researcher's calculations

The other important factor which has found to have a negative and statistically significant on technical inefficiency is the main occupation. In general, Libyans prefer to work in the services sector and most of them practice their farm work as part-time. Some farmers found to be depending on farm work as the main source of income while it is not profitable. However, recently there are more farmers that have started to practice farm work as their main source of income. Studies have found that farmers who practice farm work as the main occupation are more efficient than those who practice them as a secondary job. The possible explanation is that full-time farmers tend to focus on their work, since, it is their main source of income, thus, putting in extra efforts to ensure they work economically and to be profitable. Njeru (2010), Bhatt and Bhat (2014) and Mburu et al. (2014) also found a positive effect of the main occupation on technical efficiency.

The coefficient of farms experience is negative and statistically significan indicating that, the more experience farmers are the high technically efficient they would be, this result is consistent with the results of Chepng'etich et al. (2015), Hashmi et al. ( 2015). The household size is one of the most important factors which has a negative consequence on technical inefficiency but statistically insignificant. The effect of age of farmers and farmer's experience supposed to be in the same line but it was in the different direction. The possible explanation for that is older farmers gained farm work recently after retirement that led them to become less experience, although, the advanced age, Table 7 represents the cross tabulation between the age of farmers with the years of experience can explain this view.

About $41 \%$ of farmers who ages between $51-60$, their experience ranged between 11-15 indicating that the farmers in this range at least started farming worked between the age of $39-49$ years and $19 \%$ of farmers start farm work at the age ranged between $46-50$ years.

Seed type is also one of the most important factors affecting efficiency. The positive relationship between seed type and technical inefficiency shows that farmers planting non-improved seeds show increased in technical inefficiency and the possible reason of this is because the improved seeds have been tailored to enable the farmers to harvest higher yields as well as resist some crop diseases and pests.

\section{CONCLUSION}

The result shows that wheat farmers have a great chance to enhance their production and productivity by improved use of the inputs. This study used an SBM Model to estimate technical efficiency for a sample of 225 farmers in the Fezzan Region, Libya. On average, the farmers can decrease their input by $24 \%$ and still produce the same level of output. The study concludes that farmers were not optimizing on their wheat outputs, mainly due to the fact that most of the inputs used for wheat production had slacks. Mean slack per hectare was 5.69 man-day, $65.68 \mathrm{~kg}, 30.21 \mathrm{~kg}, 22.88 \mathrm{~kg} / \mathrm{ha}$ and $13.67 \mathrm{~kg}$ for labor, seed, DAP, organic fertilizer and urea, respectively. Therefore, farmers can be fully efficient by decreasing the values of input slacks from the inputs used. Experience, seed type, household size, main occupation and age of farmers were identified as the major determinants of TE.

\section{RECOMMENDATIONS}

Furthermore, the government can focus on younger farmers to improve wheat planting and take serious steps in using modern technology to raise the productivity of wheat. In addition, the use of improved seed with recommended, rates was promoted through the more efficient transfer of technologies in the study area.

In summary, the study concluded that farmers were not optimizing on their wheat outputs, mainly due to the fact that most of the inputs used for wheat production had slacks. Thereby, the study justifies one of the reasons for the continued low level of wheat productivity by the low level of technical efficiency and wheat farmers could improve their production and productivity by better use of inputs. The main contribution of the study is to determine the technical efficiency of wheat farmers associated with the resources used by the slacks analysis in which many of literature ignored this part. The results help inefficient farmers to become effective farmers and manage their inputs better. On the other hand, this study provides a clear picture of the performance of wheat farmers in Libya which is one of the few studies that discussed the efficiency accompanied by the impact of socioeconomic factors of wheat farmers in Libya

However, this study was conducted during the period of political instability in Libya and there were economic and security problems in the country which made getting some data difficult. Consequently, the model used in this 
study was limited because it does not include factors like machines, horses and others which could affect technical efficiency thereby; future study should include these variables in the model. On the other hand, this study focused on Southwestern Libya and it is important for future studies to cover all parts of Libya and to highlight the impact of environmental conditions on the efficiency of wheat producers. In addition, to increase the importance of the results, it is better for future studies to increase other socioeconomic factors in the inefficiency analysis such as subsidies and distance from the market, etc. Nevertheless, this limitation does not reduce the importance of this study, since, it not only shows us the level of technical efficiency of wheat farms in Libya but also determined the factors that cause technical inefficiency.

\section{REFERENCES}

Ahmed, M.A., Z.A. Mohamed, N.M. Nawi and A. Illiyasu, 2016. Technical efficiency analysis of smallholder maize farmers in North Eastern Nigeria. Br. J. Econ. Finance Manage. Sci., 12: 24-33.

Ajekiigbe, N.A., A.B. Ayanwale, D.J. Oyedele and O.C. Adebooye, 2017. Technical efficiency in production of underutilized indigenous vegetables. Intl. J. Veg. Sci., 24: $1-9$.

Ali, S. and M. Khan, 2014. Estimation of technical efficiency of wheat farming in Khyber Pakhtunkhwa, Pakistan: A stochastic frontier approach. Intl. J. Inn. Appl. Stud., 8: 177-184.

Arthi, V., K. Beegle, J. De Weerdt and A. Palacios-Lopez, 2018. Not your average job: Measuring farm labor in Tanzania. J. Dev. Econ., 130: 160-172.

Bai, H. and F. Tao, 2017. Sustainable intensification options to improve yield potential and eco-efficiency for rice-wheat rotation system in China. Field Crops Res., 211: 89-105.

Banker, R.D., A. Charnes and W.W. Cooper, 1984. Some models for estimating technical and scale Inefficiencies in data envelopment analysis. Manage. Sci., 30: 1078-1092.

Bhatt, M.S. and S.A. Bhat, 2014. Technical efficiency and farm size productivity-micro level evidence from Jammu and Kashmir. Intl. J. Food Agric. Econ., 2: $27-47$.

Boundeth, S., T. Nanseki and S. Takeuchi, 2012. Analysis on technical efficiency of maize farmers in the northern province of Laos. Afr. J. Agric. Res., 7: 6579-6587.
Buriro, R.A., A.A. Khooharo, G.H. Talpur and M.I. Rajput, 2013. Technical efficiency of wheat farming in Sindh Province of Pakistan. Pak. J. Agri. Agric. Eng. Vet. Sci., 29: 77-87.

Charnes, A., W.W. Cooper and E. Rhodes, 1978. Measuring the efficiency of decision making units. Eur. J. Operat. Res., 2: 429-444.

Chebil, A., A.A. Hashim, A.O. Hassan, I. Abdalla and I. Tahir et al., 2016. Metafrontier analysis of technical efficiency of wheat farms in Sudan. J. Agric. Sci., 8: 179-186.

Chepng'etich, E., S.O. Nyamwaro, E.K. Bett and K. Kizito, 2015. Factors that influence technical efficiency of sorghum production: A case of small holder sorghum producers in Lower Eastern Kenya. Adv. Agric., 2015: $1-11$.

Chirwa, E.W., 2007. Sources of technical efficiency among smallholder maize farmersin Southern Malawi. AERC Research, pp: 172.

Dagistan, E., 2010. Determination of technical efficiency in wheat (Triticum aestivum L.) production of Turkey: A case study of Cukurova region. J. Food Agric. Environ., 8: 354-358.

Farrell, M.J., 1957. The measurement of productive efficiency. J. R. Stat. Soc. Ser. A, 120: 253-290.

Gambo, D., S.N. Muhammad, G. Abel and L. Muhammad, 2017. Impact of IFAD community based agriculture and rural development programme on participants and non-participants farm production efficiency in Katsina State, Nigeria. Net J. Agric. Sci., 5: 1-7.

Ghaderzadeh, H. and M.H. Rahimi, 2008. Estimation of technical efficiency of wheat farms: A case study in Kurdistan province of Iran. Am. Eurasian J. Agric. Environ. Sci., 4: 104-109.

Hashmi, M.S., M.A. Kamran, K. Bakhsh and M.A. Bashir, 2015. Technical efficiency and its determinants in wheat production: Evidence from the Southern Punjab, Pakistan. J. Environ. Agric. Sci., 3: 48-55.

Ibrah, A.A.A. and H.S. Mohamed, 2015. Technical efficiency of wheat farms in river Nile State, Sudan. Master Thesis, NAF, New York, USA.

Isin, S., F. Isin and A. Uzmay, 2013. Technical and economic efficiency in cotton production in the Aegean region, Turkey. J. Food Agric. Environ., 11: 1682-1686.

Julie, T.N., F.D. Engwali and B. Jean-Claude, 2017. Technical efficiency of diversification versus specialization of vegetable-based farms in the west region of Cameroon. Am. J. Agric. For., 5: 112-120. 
Kalra, B.S., B. Mondal and A. Sarangi, 2015. Technical efficiency of wheat and paddy farms in irrigated saline environment in Haryana State, India: An assessment. Afr. J. Agric. Res., 10: 637-644.

Khanal, N.P., K.L. Maharjan and A. Sapkota, 2012. Technical efficiency in wheat seed production: A case study from Tarai region of Nepal. J. Intl. Dev. Cooperation, 19: 41-50.

Koopmans, T.C., 1951. Efficient allocation of resources. Econometrica J. Econometric Soc., 19: 455-465.

Lariel, N., 2015. Challenges in the sustainability of Libyan agriculture: Opportunities for the Libyan seed system. Ph.D Thesis, Colorado State University, Fort Collins, Colorado.

Mburu, S., C. Ackello-Ogutu and R. Mulwa, 2014. Analysis of economic efficiency and farm size: A case study of wheat farmers in Nakuru District, Kenya. Econ. Res. Intl., 2014: 1-10.

Mirza, F.M., N. Najam, M. Mehdi and B. Ahmad, 2015. Determinants of technical efficiency of wheat farms in Pakistan. Pak. J. Agric. Sci., 52: 565-570.

Njeru, J., 2010. Factors Influencing Technical Efficiencies Among Selected Wheat Farmers in Uasin Gishu District, Kenya. African Economic Research Consortium, Nairobi, Kenya, ISBN:9966-778-76-4, .

Rahman, M.S., M.M. Miah and S. Hossain, 2011. Impact of farm mechanization on labour use for wheat cultivation in northern Bangladesh. J. Anim. Plant Sci., 21: 589-594.

Sapkota, M., N.P. Joshi, R.R. Kattel and M. Bajracharya, 2017. Technical efficiency and its determinants on Maize Seed Production in Palpa District, Nepal. J. Agric. For. Univ., 1: 1-15.
Sav, G.T., 2017. Efficiency evaluations of US public higher education and effects of state funding and pell grants: Panel data estimates using two stage data envelopment analysis, 2004-2013 academic years. J. Educ. Finance, 42: 357-385.

Singh, Y.S. and B. Bera, 2016. Resource use efficiency in rice cultivation in Manipur. J. Crop Weed, 12: 36-39.

Tavva, S., A. Aw-Hassan, J. Rizvi and Y.S. Saharawat, 2017. Technical efficiency of wheat farmers and options for minimizing yield gaps in Afghanistan. Outlook Agric., 46: 13-19.

Tiruneh, W.G. and E. Geta, 2016. Technical efficiency of smallholder wheat farmers: The case of Welmera district, Central Oromia, Ethiopia. J. Dev. Agric. Econ., 8: 39-51.

Tone, K., 2001. A slacks-based measure of efficiency in data envelopment analysis. Eur. J. Oper. Res., 130: 498-509.

Tone, K., 2017. Advances in DEA Theory and Applications: With Extensions to Forecasting Models. John Wiley \& Sons, Hoboken, New Jersey, USA., ISBN:9781118946695, Pages: 541.

Torgersen, A.M., F.R. Forsund and S.A.C. Kittelsen, 1996. Slack-adjusted efficiency measures and ranking of efficient units. J. Prod. Anal., 7: 379-398.

Usman, M., W. Ashraf, I. Jamil, M.A. Mansoor and Q. Ali et al., 2016. Efficiency analysis of wheat farmers of District Layyah of Pakistan. Am. J. Exp. Agric., 11: 1-11.

Wilson, P., D. Hadley and C. Asby, 2001. The influence of management characteristics on the technical efficiency in UK potato production. Agric. Econ., 24: 329-338. 